\title{
Participação / Participation
}

https://doi.org/10.21814/uminho.ed.36.48

\section{Cath Larkins}

The Centre for Children and Young People's Participation, University of Central Lancashire, United Kingdom 



\section{Participação}

A participação emergiu como uma noção proeminente nos Estudos da Infância. Está associada às ideias de voz, envolvimento, agência, poder e influência nas vidas pessoais, serviços, política e tomadas de decisão. Mas a participação também pode ser sobre os contributos materiais para a família, as comunidades ou a sociedade mais alargada ou mesmo fazer parte da educação. Como a participação é definida e entendida varia entre os indivíduos e os sectores, os contextos culturais e económicos e a língua.

Roger Hart desenvolveu um conceito sobre a participação das crianças a partir de uma abordagem que considera diferentes formas de ação das crianças, desde o "tokenismo" até à cidadania, de acordo com a forma como as crianças são informadas, iniciam ideias, são consultadas, lideram ou dirigem iniciativas. A sua concetualização inspirada em Sherry Arnstein apresenta a participação do cidadão a partir de uma escada, mostrando uma ligação entre a participação das crianças e as discussões da participação dos adultos, particularmente no trabalho comunitário e de desenvolvimento. Hart, posteriormente, considerou que mais do que usar a escada como uma ferramenta de avaliação, seria mais relevante considerar diferentes formas da participação das crianças, que dependem das circunstâncias.

Um texto chave é o de 1989, da Convenção das Nações Unidas sobre os Direitos das Crianças, especificamente os artigos $12 .^{\circ}-17 .^{\circ} \mathrm{O}$ artigo $12 .^{\circ}$ assegura que os Estados devem garantir "à criança com capacidade de discernimento o direito de exprimir livremente a sua opinião sobre as questões que the respeitem, sendo devidamente tomadas em consideração as opiniões da criança, de acordo com a sua idade e maturidade". Os Estados Partes são obrigados a respeitar, proteger e promover o direito das crianças a expressar os seus desejos e para estes serem tidos em conta nas decisões que os afetam e ser dada oportunidade às crianças de serem ouvidas em procedimentos judiciais. Outros artigos relevantes asseguram os direitos à liberdade de expressão (Artigo 13. ${ }^{\circ}$ ), liberdade de pensamento, consciência e religião (Artigo 14. ${ }^{\circ}$ ), o direito de associação com outros (Artigo 15..$^{\circ}$ ), o direito à privacidade (Artigo $16^{\circ}$ ) e o direito de acesso à informação (Artigo $17 .{ }^{\circ}$ ). Interpretações e orientações sobre a implementação do Artigo $12 .{ }^{\circ}$ da Convenção das Nações Unidas sobre os Direitos da Criança são detalhadas 
no Comentário Geral n. ${ }^{\circ}$ 12. Os Comentários Gerais afirmam que a capacidade das crianças terem voz deve ser presumida e avaliada num nível individual; distinções baseadas na idade, relativas à capacidade de ter voz, não devem ser feitas na lei ou na prática. A capacidade para a tomada de decisão independente aumenta à medida que aumentam as oportunidades para formar e contribuir com pontos de vista, mais do que considerar uma trajetória biológica. O Comentário Geral indica que a frase "assuntos que as afetam" deve ser amplamente interpretada para incluir assuntos individuais e coletivos relacionados com a família, acolhimento residencial, saúde, educação, ócio, atividades culturais, trabalho, situações de violência, estratégias de prevenção, imigração e procedimentos de asilo e situações de emergência. 0 Comentário Geral também reconhece barreiras sociais, culturais, políticas e económicas que precisam de ser desmanteladas de forma a criar ambientes onde a criança se possa capacitar, ser ouvida e influenciar decisões. A nível europeu, A Recomendação do Conselho da Europa sobre a Participação das crianças e dos jovens com idades inferiores a 18 anos (2012) e a Recomendação da União Europeia sobre o Investimento nas Crianças também colocam a ênfase no requerimento para que os Estados permitam às crianças expressar individual e coletivamente os seus pontos de vista nos processos de tomada de decisão. Uma abordagem mais radical à participação das crianças pode ser traçada por noções de protagonismo; há uma crescente consideração de que a ação autodirigida das crianças, o ativismo intergeracional, a participação em movimentos sociais associados ao trabalho e à desobediência, possam ser considerados como formas de participação.

A participação é então, mais do que um direito, um conceito, que ajuda a pensar as formas como as pessoas comunicam, exercem poder, adquirem influência e socialmente contribuem ou experienciam a exploração. 0 posicionamento crítico em relação à da participação implica afastar-se das ideias do mundo liberal minoritário que sugere que a participação é uma performance que acontece em determinados lugares. As crianças comunicam e exercem influência nos espaços familiares, nas ruas, nas comunidades, nas instituições e nos relacionamentos entre profissionais-criança. Isto é alcançado através das suas ações dentro e com os seus ambientes, quando podem estar sozinhos ou com os outros, assim como através do seu envolvimento emocional e das formas de comunicação escolhidas. Modos relacionais de explorar aquelas experiências vividas foram desenvolvidas, tendo como foco o tentar entender as dinâmicas criança-criança, criança-adulto, e criança-relações (não) materiais. Estas abordagens relacionais ajudam a expandir a ideia de voz, para que as ideias da comunicação não 
se foquem somente no que a criança diz, mas naquilo que ela comunica através das suas ações e nos silêncios daquilo que não diz. Estão também focadas naquilo que as crianças fazem.

Há um risco em deslocar as definições da participação da comunicação para a ação, já que se articula com conceções de participação, como uma contribuição ou responsabilidade que se requer. As crianças são por vezes descritas como participantes quando estão a trabalhar em atividades que elas não escolheram, ou quando estão simplesmente a frequentar atividades educativas para as quais se requer legalmente que participem. Quando o termo participação é usado desta forma, ele deve ser sublinhado, e deve haver cuidado ao considerar até que ponto a participação é usada, por exemplo, para se referir a trabalho, conformidade, influência ou ativismo.

\section{Participation}

Participation has emerged as a prominent notion in childhood studies. It is associated with ideas of voice, involvement, agency, power and influence in personal lives, practice, research, services, policy and political decision-making. But participation can also be about material contributions to family, communities and wider society or even taking part in education. How participation is defined and understood varies between individuals and sectors, across cultural and economic contexts and according to language.

Roger Hart developed a concept paper on children's participation as an approach to engaging with children. In this influential paper, participation was defined as varying from tokenism to citizenship according to the extent to which children are informed, initiate ideas, are consulted, lead or direct initiatives. His conceptualisation follows Sherry Arnstein, who presents citizen participation as a ladder, showing a link between children's participation and early discussions of adult participation, particularly in community work and development work. Hart has subsequently noted the need to place the ladder on its side, rather than use it as a tool of assessment, and consider different forms of children's participation as relevant, depending on circumstances.

A key text is the 1989 United Nations Convention on the Rights of the Child (UNCRC), and specifically articles 12-17 of this. Article 12 asserts "to the child who is capable of forming his or her own views the right to express those views freely in all matters affecting the child, the views of the child being given due weight in accordance with the age and maturity of the child". State parties 
are obliged to respect, protect and promote the right for children to express their wishes and for these to be taken into account in decisions that affect them and to provide opportunities for children to be heard in judicial proceedings. Other relevant articles assure the rights to freedom of expression (Article 13), freedom of thought, conscience and religion (Article 14), the right to associate with others (Article 15), the right to privacy (Article 16) and the right to access information (Article 17).

Interpretation and guidance on the implementation of UNCRC Article 12 are detailed in General Comment No. 12. The General Comment states that children's capacity for voice should be presumed and assessed at an individual level; broad age-based distinctions regarding an assumed capacity for voice should not be made in law or practice. The capacity for independent decision making increases as opportunities for forming and contributing views increase, rather than according to an assumed biological trajectory.

The General Comment indicates that the phrase "matters that affect them" should be interpreted broadly to include individual and collective matters related to family, alternative care, health, education, recreation, cultural activities, work, situations of violence, prevention strategies, immigration and asylum proceedings, and emergency situations. The General Comment makes it clear that Article 12 must be respected in order to complete an adequate assessment of children's best interests. The General Comment also recognises that social, cultural, political and economic barriers need to be dismantled in order to create environments in which children can build capacity, be heard and influence decisions.

At a European level, The Council of Europe's (2012) Recommendation on the participation of children and young people aged under 18 and The European Union Recommendation on Investing in Children also place emphasis on requirements for states to enable children to express their views individually and collectively in decision making processes. A more radical approach to children's participation can be traced to notions of their being protagonists; there is growing awareness that children's self-directed action, intergenerational activism, engagement in social and labour movements and disobedience, can all be considered forms of participation.

Participation is therefore far more than a right. It is a concept, which helps think through the ways in which people communicate, exercise power, achieve influence, and socially contribute or experience exploitation. A critical consideration of participation involves removing the liberal minority 
world ideas that suggest that participation is a performance in places to which invitation has been issued. Children communicate and exercise influence in the everyday spaces of families, streets, communities, institutions and professional-child relationships. Influence is achieved through children's actions in and with their environments, when they may be alone or with others, as well as through their emotional engagements and chosen forms of communication. Relational modes of exploring these lived experiences have developed, focusing on trying to understand the dynamics of child-child, child-adult and child-(non)material relations. These relational approaches help expand the idea of voice, so that ideas of communication are not just focused on what children say, but on what they communicate through their actions and in the silences of what is unspoken. It also focuses on what children do.

There is a risk in moving definitions of participation away from communication to action, as it links to conceptions of participation as a required contribution or responsibility. Children are sometimes described as participating when they are labouring in activities that they have not chosen, or when they are simply attending educational activities in which they are legally required to participate. When the term participation is used in this way, it should be highlighted, and caution should be exercised to consider whether the term participation is being used to refer to, for example, labour, compliance, influence or activism.

\section{Referências / References}

E. Kay M. Tisdall \& P. Cuevas-Parra (2021). Beyond the familiar challenges for children and young people's participation rights: the potential of activism. The International Journal of $\mathrm{Hu}$ man Rights. DOI: 10.1080/13642987.2021.1968377

Kiili, J. \& Larkins, C. (2016). Invited to labour or participate: intra- and inter-generational distinctions and the role of capital in children's invited participation. Discourse: Studies in the Cultural Politics of Education, 39(3), 408-421. DOI: 10.1080/01596306.2016.1274290.

UN Committee on the Rights of the Child (2009). General Comment No.12. The right of the child to be heard CRC/C/GC/12, 1 July 2009. 